\title{
Immunotherapy in hepatocellular carcinoma: the complex interface between inflammation, fibrosis, and the immune response
}

\author{
Bridget P. Keenan ${ }^{1,2^{*}}$ (D), Lawrence Fong ${ }^{1,2}$ and Robin K. Kelley ${ }^{1,2}$
}

\begin{abstract}
Hepatocellular carcinoma (HCC) is the third leading cause of cancer deaths worldwide and confers a poor prognosis. Beyond standard systemic therapy with multikinase inhibitors, recent studies demonstrate the potential for robust and durable responses from immune checkpoint inhibition in subsets of HCC patients across disease etiologies. The majority of HCC arises in the context of chronic inflammation and from within a fibrotic liver, with many cases associated with hepatitis virus infections, toxins, and fatty liver disease. Many patients also have concomitant cirrhosis which is associated with both local and systemic immune deficiency. Furthermore, the liver is an immunologic organ in itself, which may enhance or suppress the immune response to cancer arising within it. Here, we explore the immunobiology of the liver from its native state to chronic inflammation, fibrosis, cirrhosis and then to cancer, and summarize how this unique microenvironment may affect the response to immunotherapy.
\end{abstract}

Keywords: Immunotherapy, Hepatocellular carcinoma, Checkpoint blockade, Liver cancer, Immunology, Fibrosis

\section{Main text Introduction}

Hepatocellular carcinoma (HCC) is a disease with both a grim prognosis and rising incidence. The most up to date estimates demonstrate a median overall survival of 9 months for all stages of untreated HCC, a number that worsens with increasing Barcelona Clinic Liver Cancer (BCLC) stage [1]. In the world, liver cancer is the third leading cause of cancer mortality while in the United States, it is the fourth highest cause [2, 3]. The rising incidence of liver cancer in the United States is attributed to the epidemics of hepatitis $C$ virus infection and nonalcoholic fatty liver disease $[4,5]$. For early stage HCC, standard of care treatments include resection, localized therapies such as ablation and radiation, and liver transplantation [6]. Until recently, the only first line systemic

\footnotetext{
* Correspondence: bridget.keenan@ucsf.edu

'Division of Hematology/Oncology, Department of Medicine, University of California San Francisco, Room M1286, 505 Parnassus Ave., San Francisco, CA 94143, USA

${ }^{2}$ Helen Diller Family Comprehensive Cancer Center, University of California San Francisco, San Francisco, CA, USA
}

therapy approved for advanced HCC was the antiangiogenic multikinase inhibitor sorafenib, based upon prolongation of median survival by approximately 3 months with low rates of tumor radiographic response, attributed to a mechanism of disease stabilization [7].

Immunotherapy is a cancer treatment strategy that has been explored for many years but only recently has seen clinical success, mainly in the form of immune checkpoint inhibitors. Antibodies to the immune checkpoints PD-1, CTLA-4, and PD-L1, have proved to be relatively safe and beneficial in treating triple negative breast cancer, renal cell carcinoma, melanoma, urothelial carcinoma, squamous cell carcinomas of the head and neck, Merkel-cell carcinoma, and non-small cell lung cancer, among others [8-14]. Checkpoint inhibition (CPI) blocks the negative regulatory signals either directly on $\mathrm{T}$ cells or on cells that interact with $\mathrm{T}$ cells (such as tumor cells, stromal cells, and antigen-presenting cells), providing a stimulus to preexisting anti-tumor immunity. Recently, two PD-1 inhibitory monoclonal antibodies, pembrolizumab and nivolumab, received regulatory approvals in the second-line setting for advanced HCC as monotherapy $[15,16]$. There 
is also early phase clinical trial data demonstrating activity from anti-CTLA-4 inhibition alone and in combination with transcatheter arterial chemoembolization (TACE) or ablation in a subset of patients $[17,18]$. Response rates range from 10 to $25 \%$ among the different checkpoint inhibitors used, and clinical data are reviewed more extensively elsewhere $[19,20]$. Moreover, despite the potential concern for relatively worse toxicity related to CPI due to already poor liver function in the HCC population, overall clinical trials have shown an acceptable safety profile for HCC patients, with rates of immune-related toxicity similar to that in patients with other tumor types and without underlying hepatic dysfunction $[21,22]$.

The site of HCC development, the liver, makes immunotherapy a promising yet complicated strategy for treatment. First, the liver itself is an immune organ, with rich populations of immune cells, some of which are unique to the liver such as Kupffer cells [23]. As there are elements that can promote both tolerance and anti-tumor immunity within the liver, evidence for the use of CPI in HCC must be inferred from model systems and from the clinical data. In other solid tumor types, metastases to the liver portend a poor response to CPI and are associated with decreased tumor infiltration of $\mathrm{CD}^{+} \mathrm{T}$ cells, demonstrating the power of the liver to generate tolerance to tumors derived from other sites [24]. Multiple examples from mouse models further substantiate the induction of systemic tolerance when exogenous antigens are expressed in hepatocytes, an effect mediated by $\mathrm{T}$ regulatory cells (Tregs) $[25,26]$. Conversely, NK and NK T cells are thought to be potent anti-cancer effector cells, of which the liver has a particular abundance [27-29]. Next, upwards of $80-90 \%$ of HCC arises in the context of underlying liver injury which can progress to fibrosis or cirrhosis; therefore, it is important to take into account the variable effects on the immune microenvironment in this state of fibrosis and chronic inflammation [30]. Lastly, the toxic and viral insults that promote carcinogenesis in the liver may drive immunosuppression directly through host/viral interactions or via chronic inflammation, although conversely, pathogen-associated molecules could serve as a source of neo-antigens to be recognized by effector $\mathrm{T}$ cells [31]. Thus, there is a tightly interwoven, exceedingly complex, relationship of chronic inflammation and the anti-cancer immune response in the liver which may represent an opportunity for CPI in HCC, but also demands thoughtfully designed treatment strategies to subvert suppressive mechanisms.

\section{Normal liver biology: a complex balance between tolerance and immunity}

The liver is an immune organ made up in bulk by hepatic parenchymal cells. Besides the biliary epithelium, the majority of the remaining $20 \%$ are non-parenchymal cells such as stellate cells, macrophages, NK, and T cells including $\mathrm{TCR} \gamma \delta \mathrm{T}$ cells (Table 1, Fig. 1) [32, 33]. The unique anatomy of the liver puts lymphocytes in direct apposition to hepatocytes through the lack of a basement membrane in liver sinusoids [32]. Due to the chronic antigen load from the gastrointestinal tract, the liver needs to maintain a level of tolerance to balance elimination of gut bacterial pathogens while avoiding severe inflammation induced by non-pathogenic gut commensals. The liver also serves as a major producer of immune-related molecules like C-reactive protein (CRP) and soluble pattern recognition receptors (PRRs) for molecules derived from pathogenic organisms, thus playing a central role in systemic inflammation and immunity [33].

There are many cell types and molecules involved in maintaining tolerance to gut antigens. Kupffer cells, which are tissue macrophages that develop independent of bone marrow-derived infiltrating monocytes, are located in the lumen of liver sinusoids and are exposed to microbial products, comprising the first line of defense (and tolerance) to pathogens [34]. Kupffer cells are activated by LPS, the complement system, and other pathogenassociated molecular patterns (PAMPs), through the expression of Toll-Like Receptors (TLRs), including TLR2, TLR3, and TLR4, to recognize microbial antigens and signals from damaged hepatocytes [23, 35]. The cytokines produced by Kupffer cells in response to TLR signaling subsequently recruit and activate neutrophils $[35,36]$. Neutrophils ingest bacteria, undergo apoptosis following destruction of pathogens, and then are cleared by Kupffer cells which dampens inflammation [36]. Compared to monocyte-derived macrophages, Kupffer cells favor tolerance by expression of IL-10 which induces Tregs and PDL1 under steady-state conditions [23, 37]. Kupffer cells are also the first line of defense from cancer cells derived from other organs that metastasize to the liver [38]. Further contributing to tolerance, monocytes and dendritic cells (DCs) can be recruited to the liver from the bone marrow; once there, cytokines such as macrophage colonystimulating factor and hepatocyte growth factor induce a tolerogenic phenotype [39].

Two non-bone marrow-derived cell types unique to the liver, liver sinusoidal endothelial cells (LSECs) and hepatic stellate cells (HSCs), are critical to these interactions with gut flora and mediation of tolerance by the liver. Liver sinusoidal endothelial cells (LSECs) are specialized endothelial cells which sample portal venous blood and act as antigen-presenting cells (APCs) with the ability to cross-prime $\mathrm{T}$ cells [40, 41]. LSECs constitutively express TLR4 resulting in $\mathrm{NF} \kappa \mathrm{B}$ signaling and produce inflammatory cytokines and reactive oxygen species in response to LPS [35, 42]. HSCs are specialized fibroblasts that can transition to myofibroblasts capable of producing extracellular matrix proteins which can lead to fibrosis and 
Table 1 Immune cell functions and alterations across the spectrum of healthy liver, fibrosis, and hepatocellular carcinoma

\begin{tabular}{|c|c|c|c|c|c|c|}
\hline \multicolumn{7}{|l|}{ Condition } \\
\hline Cell type & Healthy Liver & References & $\begin{array}{l}\text { Fibrosis and chronic } \\
\text { inflammation }\end{array}$ & References & Hepatocellular carcinoma & References \\
\hline $\mathrm{CD}^{+} \mathrm{T}$ cell & $\begin{array}{l}\text { Provide protection against } \\
\text { infection }\end{array}$ & [32] & $\begin{array}{l}\text { Progressive dysfunction and } \\
\text { exhaustion, PD-1 upregulation } \\
\text { with chronic inflammation and } \\
\text { viral infection }\end{array}$ & [90] & $\begin{array}{l}\text { Anti-tumor antigen-specific re- } \\
\text { sponses detected; Progressive } \\
\text { dysfunction and exclusion } \\
\text { from tumors, upregulated ex- } \\
\text { haustion markers, low produc- } \\
\text { tion of granzyme B and } \\
\text { perforin, decreased } \\
\text { proliferation }\end{array}$ & $\begin{array}{l}{[96,98,} \\
116,124- \\
126]\end{array}$ \\
\hline $\mathrm{CD}^{+}$Treg & $\begin{array}{l}\text { Antigen-specific tolerance; } \\
\text { Readily expand following } \\
\text { interaction with HSCs, Kupffer } \\
\text { cells, and LSECs }\end{array}$ & $\begin{array}{l}{[25,26,} \\
37]\end{array}$ & $\begin{array}{l}\text { Secrete IL-10 and TGF } \beta \text {; Inhibit } \\
\text { CD8 }{ }^{+} \mathrm{T} \text { cell responses; Pro- } \\
\text { mote B cell activation and pro- } \\
\text { duction of IgG through CD40- } \\
\text { CD40L interaction }\end{array}$ & {$[84,85]$} & $\begin{array}{l}\text { Increased numbers of Tregs } \\
\text { found within liver tumors; } \\
\text { Suppress CD } 8^{+} \mathrm{T} \text { cell } \\
\text { production of perforin and } \\
\text { proliferation; Inhibit CD4 } \\
\text { effector T cell proliferation; } \\
\text { Suppress NK function } \\
\text { including cytotoxicity and IFNy } \\
\text { production }\end{array}$ & $\begin{array}{l}{[96-98,} \\
107]\end{array}$ \\
\hline $\mathrm{CD}^{+}$Th cell & $\begin{array}{l}\text { Anti-microbial protective } \\
\text { immunity; Regulators of pro- } \\
\text { and anti-inflammatory signals }\end{array}$ & {$[32,37]$} & $\begin{array}{l}\text { Decreased numbers of naïve } \\
\text { CD4 }^{+} T \text { cells in circulation in } \\
\text { cirrhotic patients; Increased } \\
\text { numbers of Th17 cells, IL-17 } \\
\text { can promote fibrosis via acti- } \\
\text { vation of stellate cells }\end{array}$ & $\begin{array}{l}{[37,83,87,} \\
88]\end{array}$ & $\begin{array}{l}\text { Elevated CD4/CD8 ratio } \\
\text { predictive of recurrence free } \\
\text { survival; Increased expression } \\
\text { of PD-1 and CTLA-4, De- } \\
\text { creased cytokine secretion in } \\
\text { intra-tumoral CD4 } 4^{+} \text {cells com- } \\
\text { pared to peripheral blood } \\
\text { CD4 }{ }^{+} \text {T cells }\end{array}$ & {$[96,99]$} \\
\hline B cell & $\begin{array}{l}\text { Not well characterized, few B } \\
\text { cells found in healthy liver }\end{array}$ & [32] & $\begin{array}{l}\text { Role not as well-defined; } \\
\text { found to be activated in } \\
\text { chronic liver disease }\end{array}$ & {$[85]$} & $\begin{array}{l}\text { Rarely found via IHC staining } \\
\text { of liver tumors, IgA-producing } \\
\text { cells suppress } C D 8^{+} T \text { cells }\end{array}$ & {$[94,113]$} \\
\hline 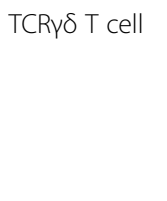 & $\begin{array}{l}\text { Recognition of peptide and } \\
\text { non-peptide ligands; Innate- } \\
\text { like and adaptive T cell protec- } \\
\text { tion from pathogens }\end{array}$ & [33] & $\begin{array}{l}\text { Production of pro- } \\
\text { inflammatory IL-17; Recruit- } \\
\text { ment of CD } 8^{+} \mathrm{T} \text { cells and Th1 } \\
\text { cells; Killing of HSCs; Promote } \\
\text { monocyte differentiation into } \\
\text { MDSCs }\end{array}$ & {$[37,86]$} & $\begin{array}{l}\text { Possible anti-tumor } \\
\text { cytotoxicity }\end{array}$ & [118] \\
\hline Kupffer cell & $\begin{array}{l}\text { Induction of tolerance to } \\
\text { commensal bacteria and food } \\
\text { particles; Recruit Tregs; } \\
\text { Recruitment and clearance of } \\
\text { neutrophils; Stimulate T cell } \\
\text { response to infection; Recruit } \\
\text { and activate NK cells via IL-12 } \\
\text { and cell:cell contact }\end{array}$ & $\begin{array}{l}{[23,28,} \\
34-37,39, \\
63]\end{array}$ & $\begin{array}{l}\text { Lose tolerogenic properties } \\
\text { under inflammatory } \\
\text { conditions; Secrete reactive } \\
\text { oxygen species, TGF } \beta \text {, PDGF, } \\
\text { TNFa, and matrix } \\
\text { metalloproteinases; Activate } \\
\text { HSCs }\end{array}$ & $\begin{array}{l}{[23,33,61,} \\
65]\end{array}$ & $\begin{array}{l}\text { Protective against tumors via } \\
\text { clearance of tumor cells; } \\
\text { Suppression of T cell function } \\
\text { via PD-L1 expression }\end{array}$ & {$[38,111]$} \\
\hline MAIT cell & $\begin{array}{l}\text { Protection against bacteria; } \\
\text { React to lipid antigens }\end{array}$ & $\begin{array}{l}{[37,43,} \\
44]\end{array}$ & $\begin{array}{l}\text { Exhausted phenotype with } \\
\text { upregulation of PD-1 and } \\
\text { CTLA-4; Capable of activating } \\
\text { HSCs }\end{array}$ & {$[92,93]$} & $\begin{array}{l}\text { Potential anti-tumor cytotox- } \\
\text { icity; Excluded from tumors } \\
\text { and found at higher frequen- } \\
\text { cies in surrounding tissue }\end{array}$ & {$[44,96]$} \\
\hline NK cell & $\begin{array}{l}\text { Anti-viral protection through } \\
\text { cytokine production and } \\
\text { cytotoxicity }\end{array}$ & [28] & $\begin{array}{l}\text { Protect against fibrosis by } \\
\text { killing of HSCs and production } \\
\text { of IFNy; Can induce liver injury } \\
\text { by worsening inflammation }\end{array}$ & $\begin{array}{l}{[27,28,} \\
33]\end{array}$ & $\begin{array}{l}\text { Cytotoxic to tumor cells; } \\
\text { Impaired function (decreased } \\
\text { granzyme and perforin, } \\
\text { decreased cytotoxicity) and } \\
\text { decreased in number in } \\
\text { tumors and peripheral blood; } \\
\text { Decreased expression of } \\
\text { KIR2DL1 and KIR2DL3 }\end{array}$ & $\begin{array}{l}{[28,94,97} \\
100]\end{array}$ \\
\hline NK T cell & $\begin{array}{l}\text { Th1-like phenotype in the } \\
\text { presence of IL-12; Th2-like } \\
\text { phenotype in the presence of } \\
\text { IL-7. Type I NK T cells: Activate } \\
\text { neutrophils and HSCs, cause } \\
\text { hepatocyte death. Type II NK T } \\
\text { cells: Suppress pro- }\end{array}$ & $\begin{array}{l}{[28,45,} \\
46]\end{array}$ & $\begin{array}{l}\text { Type I NK T cells: Activation of } \\
\text { HSCs and neutrophils, } \\
\text { production of IFNy and IL-4 } \\
\text { can worsen inflammation }\end{array}$ & {$[45,72]$} & $\begin{array}{l}\text { Type I NK T cells associated } \\
\text { with tumor control; Impaired } \\
\text { cytotoxicity, decreased } \\
\text { expression of KIR2DL1 and } \\
\text { KIR2DL3 }\end{array}$ & {$[71,100]$} \\
\hline
\end{tabular}


Table 1 Immune cell functions and alterations across the spectrum of healthy liver, fibrosis, and hepatocellular carcinoma (Continued)

\begin{tabular}{|c|c|c|c|c|c|c|}
\hline \multicolumn{7}{|l|}{ Condition } \\
\hline \multirow{2}{*}{ Cell type } & Healthy Liver & References & $\begin{array}{l}\text { Fibrosis and chronic } \\
\text { inflammation }\end{array}$ & References & Hepatocellular carcinoma & References \\
\hline & $\begin{array}{l}\text { inflammatory signaling } \\
\text { pathways. }\end{array}$ & & & & & \\
\hline $\begin{array}{l}\text { Hepatic } \\
\text { stellate cell }\end{array}$ & $\begin{array}{l}\text { Express MHC I and II; Induce } \\
\text { tolerance and anti-microbial } \\
\text { immunity; PD-L1 expression } \\
\text { leading to T cell apoptosis }\end{array}$ & {$[23,39]$} & $\begin{array}{l}\text { Differentiate to myofibroblasts; } \\
\text { Secrete matrix } \\
\text { metalloproteinases, } \\
\text { extracellular matrix } \\
\text { remodeling; Secrete IL-6, TNFa } \\
\text { and TGF } \beta \text {, Induce Th17 cells } \\
\text { and Tregs }\end{array}$ & $\begin{array}{l}{[39,59,61} \\
65,88]\end{array}$ & $\begin{array}{l}\text { Induce MDSC and polarize } \\
\text { monocytes to an } \\
\text { immunosuppressive } \\
\text { phenotype; Promote tumor } \\
\text { growth }\end{array}$ & {$[42,64]$} \\
\hline $\begin{array}{l}\text { Liver } \\
\text { sinusoidal } \\
\text { endothelial } \\
\text { cell }\end{array}$ & $\begin{array}{l}\text { Expression of } \mathrm{MHC} \mathrm{I} \text { and II; } \\
\text { Activate } \mathrm{CD} 4^{+} \text {and } \mathrm{CD} 8^{+} \mathrm{T}^{2} \text { cell } \\
\text { responses; Induce tolerance } \\
\text { via PD-L1 expression; Induc- } \\
\text { tion of Tregs }\end{array}$ & $\begin{array}{l}{[35,39,40,} \\
50]\end{array}$ & $\begin{array}{l}\text { Impaired antigen-processing } \\
\text { and lower MHC II expression } \\
\text { in the setting of fibrosis re- } \\
\text { lated to high levels of circulat- } \\
\text { ing endotoxin }\end{array}$ & [41] & $\begin{array}{l}\text { Induce tolerance to tumor- } \\
\text { derived antigens; decrease } \\
\text { ability of dendritic cells to } \\
\text { stimulate T cell responses }\end{array}$ & {$[42,47]$} \\
\hline $\begin{array}{l}\text { Bone } \\
\text { marrow- } \\
\text { derived } \\
\text { monocyte, } \\
\text { macrophage, } \\
\text { and dendritic } \\
\text { cell }\end{array}$ & $\begin{array}{l}\text { Promote tolerance to } \\
\text { commensals and food } \\
\text { particles; Stimulate T cell } \\
\text { response to infection; More } \\
\text { tolerogenic than activating in } \\
\text { healthy liver }\end{array}$ & {$[39,47]$} & $\begin{array}{l}\text { Dysfunctional antigen } \\
\text { presentation; Increased non- } \\
\text { classical monocytes; Produc- } \\
\text { tion of pro-inflammatory cyto- } \\
\text { kines (TNFa, IL-6, IL-1) }\end{array}$ & $\begin{array}{l}{[41,77,78,} \\
82,83]\end{array}$ & $\begin{array}{l}\text { Conversion to MDSC capable } \\
\text { of suppressing effector T cells, } \\
\text { inducing Tregs, and } \\
\text { promoting tumor growth } \\
\text { through pro-angiogenic cyto- } \\
\text { kine production; Conversely, } \\
\text { can control tumors via induc- } \\
\text { tion of antigen-specific T cell } \\
\text { responses; Impaired ability to } \\
\text { penetrate tumor tissue }\end{array}$ & $\begin{array}{l}{[23,42,47,} \\
64,104]\end{array}$ \\
\hline
\end{tabular}

cirrhosis in some settings, as discussed further below; they can also express MHC I and II and may play a role in $\mathrm{T}$ cell priming $[39,42]$.

Unique innate and innate-like lymphocyte populations exist in the liver, in higher abundance than in other organs or peripheral blood. Natural killer (NK) cells make up $25-40 \%$ of hepatic lymphocytes, with important roles in protecting against fibrosis and defending against cancer and viruses through potent cytotoxicity as well as production of IFNY [28]. Mucosal-associated invariant T cells (MAIT cells) have semi-invariant $\mathrm{T}$ cell receptors (TCR) and are capable of mounting an immune response to bacteria [43, 44]. Finally, NK $\mathrm{T}$ cells have semiinvariant TCR chains and recognize endogenous and exogenous lipids including those derived from gut microbes. There are two types of NK T cells (I and II) with type II being more numerous in humans; crossregulation between these cell types is essential for balance of pro and anti-inflammatory pathways in normal liver $[45,46]$ (Table 1). Although more abundant in the liver than in peripheral blood, NK T cells constitute a relatively small fraction of the total liver $\mathrm{T}$ cells and MAIT cells account for a larger portion of the innatelike $\mathrm{T}$ cells in humans compared to mice [33, 37].

Conventional $\mathrm{T}$ cells must migrate through liver endothelium and, through interaction with APCs mediated by the integrins ICAM-1 and VCAM-1, can be triggered to proliferate upon antigen encounter [37]. The liver contains abundant adaptive and innate-like $\mathrm{T}$ cells that protect against pathogens under normal conditions, with higher numbers of $\mathrm{CD}^{+}$than $\mathrm{CD} 4^{+} \mathrm{T}$ cells, and higher proportions of TCR $\gamma \delta$ cells than in the peripheral blood [32, 33, 47]. While Tregs are found at low levels (for example, in comparison to the spleen) at steady state, they are readily induced under tolerogenic conditions by HSCs, LSECs, and Kupffer cells [37, 39]. Effector T cells can be tolerized and clonally deleted following recognition of antigen by direct hepatocyte-induction of apoptosis or apoptosis due to incomplete activation [37].

Beyond cell types and liver anatomy, there are several important tolerance-mediating molecules that have an important role in healthy liver biology. Among them, TGF $\beta$ has pleiotropic effects in the liver including promoting fibrosis, carcinogenesis, and hepatocyte death, and during the steady state, is involved in liver regeneration [48]. PD-L1 is constitutively expressed by sinusoidal cells and Kupffer cells, promoting tolerance both under steady state and during viral infection [37, 49]. Additional examples of liver tolerance are documented from the literature on liver transplantation. Given the tolerogenic potential of the liver due to its role in mediating host response to gut flora, perhaps it is not surprising that some liver transplant recipients can fully accept their allograft and safely discontinue immunosuppressive medications [50]. While the full mechanisms for this are not yet fully elucidated, an NK and $\mathrm{TCR} \gamma \delta \mathrm{T}$ cell gene 


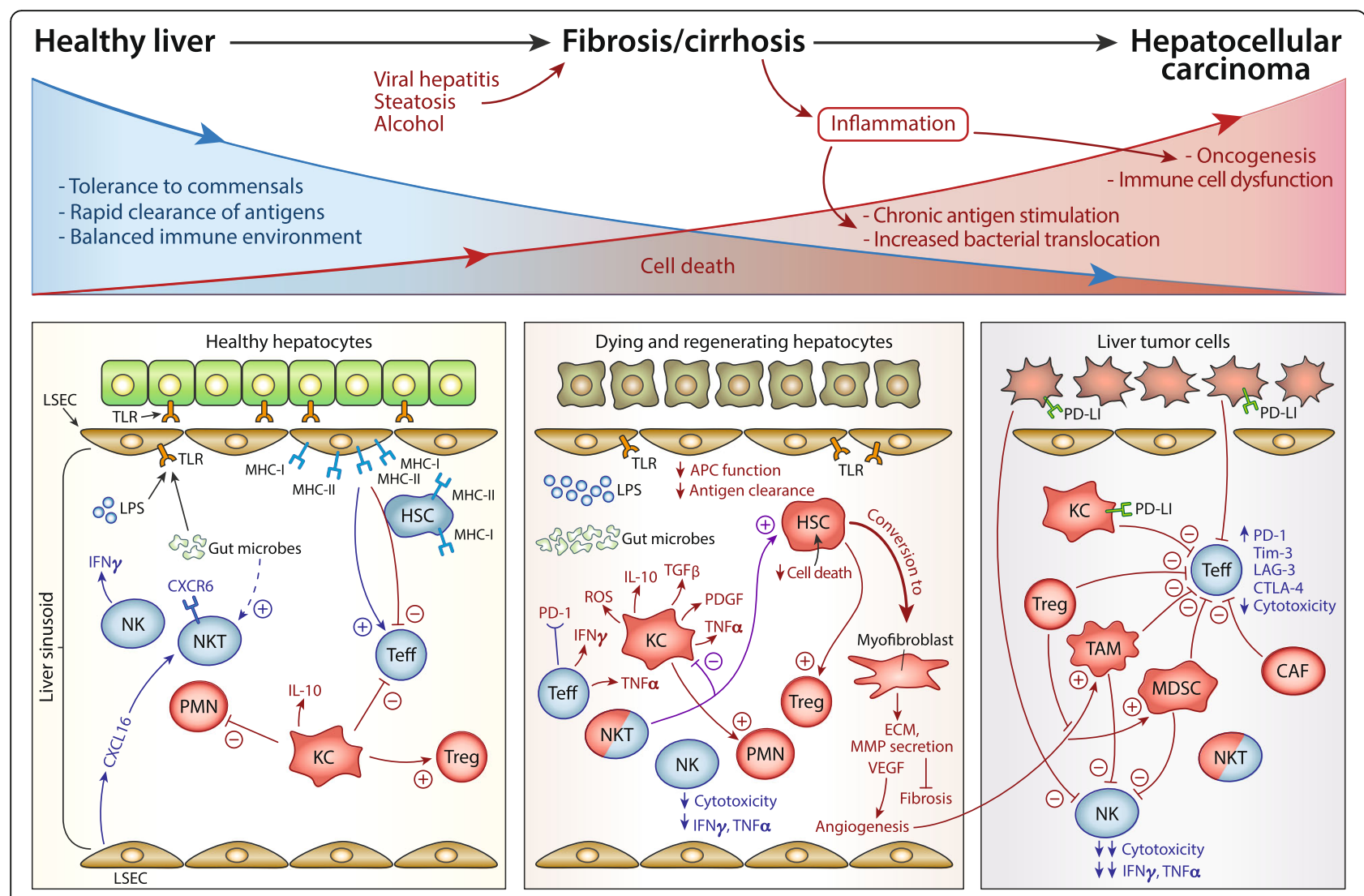

Fig. 1 Liver immunobiology across a spectrum from healthy liver to inflammation and oncogenesis. Top panel: Viral and toxic insults drive inflammation in the liver and alter the normal baseline response to gut commensals. Chronic inflammation can lead to alteration of normal immunity to both commensal organisms and pathogens, and eventually, to oncogenesis. Bottom panel: General mechanisms underlying tolerance and immunity and interactions between various cell types are outlined in each of the following states: healthy liver (left), fibrosis and cirrhosis (middle), and hepatocellular carcinoma (right). Cells that generally maintain tolerance in healthy liver and promote immune suppression and oncogenesis are colored in red while cells that favor protective anti-microbial or antitumor immunity are colored in blue

signature identifies patients who establish tolerance of their liver allograft [51]. Tregs are also important in mediating transplant tolerance in mouse models, and Treg cell therapy is an active area of research in the transplant community as a bridge to decreasing or discontinuing immunosuppression post-transplant [52, 53].

\section{Changes in the liver immune microenvironment with progression from chronic inflammation to fibrosis}

Both the systemic and local immune systems, as well as components of innate and adaptive immune systems, are altered in the setting of liver fibrosis and cirrhosis which occurs due to chronic inflammation from toxins, infectious agents, or other insults such as steatosis (Table 1, Fig. 1). It is well-known clinically that cirrhotic patients are systemically immunocompromised and infections constitute a major source of mortality in end-stage liver disease [54]. Bacterial infection and sepsis occur in part due to increased bacterial translocation through a "leaky" gastrointestinal barrier created by portal hypertension, as well as due to weakened systemic and local immunity [54-57]. The exact mechanisms related to the initiation of inflammation from each type of insult are reviewed extensively elsewhere and therefore are not discussed here. Rather, we focus on the general mechanisms involved in fibrosis initiation and changes in the immune status during progression to cirrhosis, an irreversible state that is the end-stage of fibrosis [58].

The main cell types involved in liver fibrosis initiation appear to be HSCs and Kupffer cells. As a result of inflammation due to toxins such as alcohol, steatosis, or viral infection, inflammatory cytokines activate HSCs through TLR4, which then produce extracellular matrix proteins such as collagen [59-61]. The cytokine IL-17 can drive production of pro-fibrogenic IL-6, TNF $\alpha$ and TGF $\beta$ by HSCs and Kupffer cells [62]. Mouse models of liver fibrosis demonstrate that under inflammatory conditions, Kupffer cells no longer induce tolerance to experimental antigens as they do in normal liver [63]. During liver damage, Kupffer cells produce reactive oxygen species, TGF $\beta$, and platelet-derived growth factor (PDGF) which activates HSCs [23, 33, 64]. Both Kupffer 
cells and HSCs secrete matrix metalloproteinases during chronic tissue injury which is mediated by TNF $\alpha$ and TGF $\beta$, promoting remodeling of the extracellular matrix $[65,66]$. Fibrosis and the buildup of extracellular matrix leads to a hypoxic environment which results in VEGF upregulation, which may later support tumor angiogenesis [64].

NK cells can protect against fibrosis via killing of activated HSCs, although can also drive inflammation [27, 28]. There is an inverse correlation between IFN $\gamma$ producing NKp $46^{\text {high }}$ NK cells and the degree of fibrosis in HCV-infected patients [67]. NK cell killing of HSCs and production of IFN $\gamma$ become suppressed over time with advancing fibrosis and can be further suppressed by alcohol consumption, as seen in a carbon tetrachlorideinduced fibrosis mouse model [68]. STAT1 signaling is an important negative regulator of the fibrosis pathway, opposing the effects of TGF $\beta$ secreted by HSCs and supporting NK cell cytotoxicity [69]. HSCs become more resistant to NK cell killing in later stages of fibrosis due to SOCS1 upregulation by HSCs [70]. As far as NK T cell populations' role, there may also be duality based on the particular type of NK $\mathrm{T}$ cells involved. Type I NK T cells are thought to be protective in acute liver injury but harmful in chronic inflammation as they activate HSCs and neutrophils whereas in the setting of liver tumors, type I NK $\mathrm{T}$ cells are associated with tumor control $[45,71,72]$.

As liver injury and fibrosis progress, the extracellular matrix becomes stiffer and the normal anatomy of liver is altered which can then cause impaired production of key immune molecules normally supplied by the liver such as complement pathway proteins. Cirrhotic patients have lower levels of $\mathrm{C} 3$ and $\mathrm{C} 4$ proteins than healthy controls, associated with infections and mortality, while in contrast and perhaps surprisingly, cirrhotic patients had higher levels of mannan-binding protein and opsonization [73, 74]. Another group that found while mannose-binding lectin (MBL) is not necessarily lower in cirrhotic patients compared to healthy controls, lower levels of MBL in cirrhosis are associated with an increased risk of infections [75]. As fibrosis progresses, a dysfunctional immune response feeds forward the cycle of inflammation. For example, patients with cirrhosis have higher levels of TLR2 expression and circulating endotoxin leading to exaggerated responses to bacterial products [35]. However, the TLR signaling apparatus can become dysfunctional rather than protective against infection, as with more infections seen in cirrhotic patients with TLR4 polymorphisms and with TLR2 and TLR4 dysfunction [55, 76]. Higher circulating levels of endotoxin and IL-10 in cirrhotic patients compared to healthy controls has been associated with "immune paralysis" - an inability of APCs to upregulate MHC and present antigens effectively to $\mathrm{T}$ cells [41, 77]. Patients with primary biliary cirrhosis were found to have defective Fc-Receptor mediated clearance of pathogen/antibody complexes, one proposed mechanism of the impaired phagocytosis by APCs that is seen in liver disease, although this has not been seen in alcoholic cirrhotic patients [78]. Low albumin levels in cirrhotic patients can drive neutrophil dysfunction; as albumin binds excess endotoxin, elevated endotoxin levels lead to chronic signaling in innate immune cells as a consequence of hypoalbuminemia [79]. Other proinflammatory molecules such as soluble CD163 and MCP-1, activators of macrophages, also are increased in the serum of cirrhotic patients [80,81].

The chronic high levels of pro-inflammatory chemokines and cytokines alters both systemic and local immune cell subsets from that seen in patients without liver disease. Compared to healthy controls, cirrhotic patients have an increased number of activated monocytes and specifically, more non-classical $\left(\mathrm{CD} 16^{+}\right)$monocytes, which increase with progressive fibrosis and are capable of activating HSCs $[82,83]$. Cirrhotic patients with ascites are found to have lower numbers of naïve $\mathrm{CD} 4^{+}$and $\mathrm{CD}^{+} \mathrm{T}$ cells and higher numbers of activated $\mathrm{CD} 4^{+} \mathrm{T}$ cells in the peripheral blood, as well as increased production of IL-10 and TGF $\beta$ by T cells [83, 84]. Suppressive Tregs expressing CD40 ligand occur in both mouse models of liver injury and explanted hepatitis C (HCV)positive livers [85]. IL-17, capable of activating HSCs and Kupffer cells to produce collagen via activation of the STAT3 pathway, is mainly secreted by $\mathrm{T}$ cells, including TCR $\gamma \delta$ T cells $[62,86]$. Tregs and Th17 cells are both found to be increased in more advanced HBVrelated fibrosis compared to earlier stage fibrotic livers; however, an elevated Th17/Treg ratio has been shown to correspond with higher liver stiffness measurement, a correlate of worsening liver fibrosis [87, 88]. Furthermore, chronic antigen stimulation can lead to $\mathrm{T}$ cell exhaustion, with upregulation of inhibitory receptors such as PD-1 and progressive loss of polyfunctional cytokine production [89]. Patients with chronic viral hepatitis have exhausted viral-specific $\mathrm{T}$ cells; blockade of the PD-1/PD-L1 pathway can partially reverse $\mathrm{T}$ cell dysfunction and has demonstrated some success in control of chronic viral infection [90,91]. In autoimmune liver disease, MAIT cells are also found to be exhausted with less IFNY production and upregulation of PD-1 and CTLA-4 is seen in autoimmune liver disease and hepatitis B infection [92, 93].

\section{HCC tumor immunobiology in the fibrotic liver microenvironment} Immune cell dysfunction is associated with HCC

HCC often arises in a background of inflamed liver due to toxins and infectious agents, although there are 
patients in which de novo HCC occurs without known fibrosis and cirrhosis, implying additional pathways to oncogenesis such as viral insertional mutagenesis in the case of hepatitis B virus. However, as the majority of patients that would be potential candidates for immunotherapy have HCC that occurs in the setting of liver fibrosis/cirrhosis, we focus on the immune microenvironment in the context of underlying fibrosis (Fig. 1). Studies of the structural organization of liver tumor versus surrounding non-tumor liver tissue using immunohistochemistry (IHC), and more recently, single cell RNA sequencing, show an immune gradient in the evolution from fibrosis to cirrhosis to cancer. $\mathrm{CD} 8^{+} \mathrm{T}$ cells can penetrate within the $\mathrm{HCC}$ microenvironment with surrounding $\mathrm{CD}_{4}^{+} \mathrm{T}$ cells and B cells, particularly in a subset of lymphocyte-rich tumors; however, in other IHC studies, Tregs are most abundant in central areas with $\mathrm{CD}^{+} \mathrm{T}$ cells restricted to borders of tumors [9496]. Tregs were enriched in the tumors of patients compared to peripheral blood or surrounding tissue adjacent to liver tumor [96]. CD20 ${ }^{+} \mathrm{B}$ cells and $\mathrm{CD} 56^{+} \mathrm{NK}$ cells were rare via $\mathrm{IHC}$ staining of $\mathrm{HCC}$ tumors and surrounding liver tissue; in particular, the $\mathrm{CD} 56{ }^{\text {low }} \mathrm{CD} 16^{+}$ NK cell subset, typically characterized by enhanced cytotoxicity, are decreased in peripheral blood of HCC patients versus healthy controls and within tumor versus non-tumor liver, a finding associated with more Tregs [94, 97]. Single cell analysis of immune cells from blood, tumor, and surrounding "normal" liver in HCC patients revealed predominant MAIT cells in non-tumor liver tissue and a high frequency of CTLA- $4^{\text {high }}$ Tregs and $\mathrm{CD}^{+} \mathrm{T}$ cells with upregulated exhaustion markers in tumor tissue [96]. For the most part, Tregs had unique TCRs suggesting they were not derived from other $\mathrm{CD}^{+}{ }^{+} \mathrm{T}$ cells, unlike $\mathrm{CD} 8^{+} \mathrm{T}$ cells which had higher degree of overlap in their TCR repertoire between activated and exhausted cells [96].

While $\mathrm{CD}^{+} \mathrm{T}$ cells and NK $\mathrm{T}$ cells have been shown to be protective against liver tumor cells in mouse models, $\mathrm{CD}^{+}$TIL found within $\mathrm{HCC}$ in patients have been shown to be dysfunctional with low production of granzyme and perforin, low proliferation as measured by Ki-67, and upregulation of exhaustion markers such as TIM3, LAG3, PD-L1, and CTLA-4 [29, 98, 99]. Similarly, NK and NK T cells in tumors of HCC patients were found to have lower expression of KIR2DL1 and KIR2DL3, receptors that modulate NK cytotoxicity, compared to the NK and NK T cells in livers of healthy controls [100]. The dysfunction of effector cells within the tumor microenvironment is driven directly by $\mathrm{HCC}$ tumor cells as well as indirectly by suppressive immune cells recruited to tumors. Tumor-associated fibroblasts can suppress NK cell cytotoxicity and cytokine production via signaling intermediates such as prostaglandins and indoleamine 2,3-dioxygenase (IDO) [101]. Soluble MHC class I-related chain A (MICA), an inhibitory NKG2D ligand, secreted by tumor cells, binds to NK cells, thus impairing their ability to activate DCs [102]. Myeloid-derived suppressor cells (MDSC) and tumorassociated macrophages, capable of inducing Tregs and suppressing $\mathrm{T}$ cells, are present in HCC mouse models [103] and patients [104]. Angiogenic factors such as VEGF and FGF, are highly expressed by HCC cells and recruit MDSC to tumors [105].

\section{An immunosuppressive signaling axis drives progression from chronic inflammation to HCC}

Through analysis of paired tumor and non-tumor liver samples from HCC patients, an immunosuppressive gradient has been described with increased expression of chemokine networks such as CXCR3/CXCL10 and CCR6/CCL20 which enhances macrophage and Treg recruitment to the liver [106, 107]. Layilin, a molecule not previously known to be important in $\mathrm{HCC}$ and identified with single cell RNA sequencing approaches, is upregulated in $\mathrm{CD}^{+} \mathrm{T}$ cells and Tregs and can suppress IFNy production when over-expressed in $\mathrm{CD}^{+} \mathrm{T}$ cells [96]. TGF $\beta$, a driver of liver fibrosis and oncogenesis via induction of hepatocyte apoptosis and subsequent proliferation, can also promote oncogenesis as a key molecule in the induction of Tregs, polarization of macrophages, and suppression of effector T cells [108-110]. PD-L1, expressed by Kupffer cells at baseline in healthy liver, is more highly expressed in areas of tumor compared to normal liver [111, 112].

\section{Immune system dysfunction is driven by viral and non-viral insults}

While there is likely overlap in the final pathways leading to immune suppression and oncogenesis between the different toxic and infectious insults that lead to HCC, there are also distinct pathways associated with various $\mathrm{HCC}$ etiologies. For example, IgA-producing cells in patients with fatty liver disease-related HCC have been implicated in driving oncogenesis via suppression of $\mathrm{CD}^{+} \mathrm{T}$ cells [113]. T cells from patients with NASHrelated HCC had higher levels of CTLA-4 and OX40, which was also associated with certain serum fatty acid levels; whereas patients with HCV-related HCC had higher numbers of circulating CD45RA ${ }^{-}$Tregs [114]. A recently published analysis of hepatitis B (HBV)-positive $\mathrm{HCC}$ versus non-virally related HCC using mass cytometry and RNA sequencing found several distinguishing characteristics based on etiology. In non-viral HCC, there is generally more IFN $\gamma$, IL-17, Granzyme B, and TNF $\alpha$ whereas virally-associated tumors have increased PD-1 expression on T cells, supporting a generally suppressive environment created by HBV [115]. Tregs and 
$\mathrm{CD}^{+}$resident memory $\mathrm{T}$ cells (TRM) were more abundant in tumors in $\mathrm{HBV}^{+}$patients than $\mathrm{HBV}^{-}$patients and had different transcriptome signatures, such as increased IL-10 signaling pathway in Tregs and more exhaustion-related genes in TRM in $\mathrm{HBV}^{+}$patients [115]. In contrast, TIM $-3^{+} \mathrm{CD} 8^{+} \mathrm{T}$ cells and $\mathrm{CD} 244^{+} \mathrm{NK}$ cells were more abundant in the tumors of non-viral HCC [115].

Regardless of initiating injury, impaired liver function leads to alteration of the microbiome and resulting host: microbial interactions and downstream metabolic pathways [56]. Mice treated with antibiotics to deplete gut microbes had less microbial-driven conversion of primary to secondary bile acids which resulted in enhanced CXCL16 expression and recruitment of activated type I CXCR6 $^{+}$NK $\mathrm{T}$ cells, protecting against liver tumor growth [71]. Given the effect of liver dysfunction on bacterial translocation and recent studies illuminating the role of the microbiome in response to checkpoint inhibition, there is likely many mechanisms by which the altered gut flora of patients with HCC shapes the immune response within the liver.

\section{Protective and tumor-antigen-specific immune responses in $\mathrm{HCC}$}

Effector cells that are found within tumors and peripheral blood of HCC patients are generally dysfunctional, although existence of certain effector cells and other immune mediators are shown to be associated with improved prognosis, such $\mathrm{T}$ and NK cells, suggesting a productive immune response to HCC is possible $[116,117]$. TCR $\gamma \delta$ T cells are expanded in the blood of liver cancer patients and show capability to kill tumor cells ex vivo [118]. A 14-gene panel of immune-related genes (including TNF, CD8A, IFNG, and various chemokines and TLRs) predicted prognosis in early stage but not late stage HCC, suggesting that a protective immune microenvironment can exist in early but not late stage HCC [119]. CXCL10, CCL5 and CCL2 correlated with infiltration of $\mathrm{CD}^{+} \mathrm{T}$ cells, Th1 $\mathrm{CD}^{+}{ }^{+} \mathrm{T}$ cells, and NK cells [119]. Cytokines such as IFN $\gamma$, TNFo, and TLR3 ligands could induce production of these chemokines by cancer cells which then serve to recruit T and NK cells [119]. Myeloid cells can be induced via $\mathrm{CpG}$ oligonucleotides to stimulate $\mathrm{CD}^{+} \mathrm{T}$ cells, demonstrating the dichotomous nature of myeloid compartment under different conditions [120]. Vdomain Ig suppressor of $\mathrm{T}$ cell activation (VISTA), while thought to be a negative regulator of $\mathrm{T}$ cells, is associated with better prognosis in HCC, in contrast to its association with worse outcomes in other tumor types [121-123]. The association of VISTA with tumor-infiltrating $\mathrm{CD}^{+} \mathrm{T}$ cells in HCC may be a signal of activated, albeit exhausted, effector cells that are protective against tumor progression whereas in melanoma and pancreatic cancer, VISTA was mainly expressed by myeloid subsets.
Tumor antigen-specific responses can occur in HCC, and the association of HCC with pathogens such as the hepatitis viruses may be an opportunity for targeting non-host antigens that will be recognized as foreign to the immune system. Spontaneous tumor antigen-specific $\mathrm{T}$ cell responses have been detected in $\mathrm{HCC}$, including in a patient that had a complete response following treatment with sorafenib and in another patient cohort following local or systemic chemotherapy [124, 125]. TCR sequencing identified a concentration of shared TCR $\alpha$ and $\beta$ chains in liver tumors compared to T cells in blood or adjacent non-tumor liver, implying clonal $\mathrm{T}$ cells within tumors [96]. Another group found that while there were detectable $\mathrm{T}$ cell responses to tumorassociated antigens, responses declined with advancing disease and tumor antigen-specific $\mathrm{CD} 8^{+} \mathrm{T}$ cells were dysfunctional with low production of IFN $\gamma$, Granzyme B, and perforin [126]. In a mouse model of HCC driven by virally-induced SV40 large T antigen, there is clearance of most virally-infected cells and in cells that persist, they retain expression of viral products [127]. However, despite the frequency of virally-associated HCC, the response to CPI does not occur in the same high proportion of patients as in other virally-associated cancers such as Merkel cell carcinoma, suggesting that anti-viral immune responses are not sufficient for a successful response to immunotherapy [128].

\section{Changes in the HCC tumor microenvironment with the use of CPI}

Due to limited clinical data overall thus far for the use of CPI in HCC, correlative studies using samples from CPI-treated liver cancer patients has lagged behind that in other cancer types. Therefore, most data we have regarding the changes in the liver post-CPI are derived from mouse models of HCC in which various checkpoint inhibitors have been used. In mouse models of HCC, anti-PD-1 has been shown to have activity both as monotherapy and in combination with other anti-cancer therapies. Due to the heterogeneity of models available, of which none wholly replicates the process of HCC initiation and progression in humans, the results are variable and based on the model used [129]. Importantly, anti-PD-1 has been shown to have activity in mouse models of HCC that incorporate a fibrotic liver microenvironment and that replicate findings seen in human tumors such as progressively exhausted $\mathrm{PD}-1^{+} \mathrm{CD} 8^{+} \mathrm{T}$ cells and accumulation of Tregs, as well as in patients with Child Pugh B liver dysfunction [22, 130]. Sorafenib therapy upregulated PD-L1 in orthotopic liver tumors and caused the accumulation of suppressive macrophages and Tregs which could be mitigated with a CXCR4-antagonist [131]. Anti-PD-1 showed synergy with the combination of the CXCR4 antagonist and 
sorafenib although not with sorafenib alone, demonstrating that a multi-targeted approach may be needed to overcome a suppressive microenvironment [131]. This model is particularly clinically relevant as many HCC patients will have been treated with tyrosine kinase inhibitors prior to CPI which may alter the tumor microenvironment.

To date, the published clinical trials of CPI in HCC have reported relatively limited immune profiling analyses on blood and archival tumor samples in subsets of patients. In the CheckMate040 and KEYNOTE-224 clinical trials of antiPD-1 therapy, there were no cases of HCV or HBV viral reactivation. In CheckMate040, there were transient decreases in HCV viral load in HCV-infected patients $[15,16]$. In patients with $\mathrm{HCV}$ and $\mathrm{HCC}$ treated with anti-CTLA-4, the majority had a decrease in viral load, including three patients with a transient complete viral response; however, anti-viral $\mathrm{T}$ cell responses did not correlate with tumor response [18]. In another study combining anti-CTLA-4 therapy with ablation, anti-viral responses were again seen in $\mathrm{HCV}^{+}$patients and those patients who did not have an anti-viral response also did not benefit in terms of tumor control [17]. This clinical trial included on-treatment biopsies at the time of ablation, which revealed that $\mathrm{CD} 8^{+} \mathrm{T}$ cell infiltration at six weeks after initiation of anti-CTLA-4 correlated with tumor response [17]. In other tumor types, PD-L1 has been used as a predictor of response to anti-PD-1 CPI. In CheckMate040, no association was found between radiographic response and tumor cell expression of PD-L1, whereas the KEYNOTE-224 trial of pembrolizumab, which used a combined score of the tumor and microenvironment immune cell PD-L1 expression, found a correlation between PD-L1-expression and response $[15,16]$.

\section{Conclusion}

The unique immunobiology of the liver promotes oncogenesis and tumor tolerance under conditions of fibrosis and chronic inflammation, while also presenting an opportunity for therapeutic targeting with immune checkpoint inhibitors. While toxic and pathogenic insults may provide neo-epitopes and pathways to target with anticancer agents, the background of chronic inflammation promotes immune suppression in an immune organ already predisposed towards tolerance. Beyond immune cell populations unique to the liver, other factors associated with chronic liver disease may also shape the response to immunotherapy. The microbiome has been demonstrated to predict response to CPI in other malignancies and is particularly relevant to HCC, due to the altered microbiome in the setting of gut translocation in chronic liver disease patients [56, 132]. The microbial contribution, including both gut commensals and pathogenic hepatitis viruses, to oncogenesis and response to CPI should be two key focus areas of future investigation. While mouse models cannot fully recapitulate the complex interaction of fibrosis caused by various toxic and pathogenic insults, the altered liver architecture seen in cirrhosis, and human immune cell populations unique to the liver, several relevant models have thus far demonstrated the benefits to using combination therapies to simultaneously stimulate effector $\mathrm{T}$ cells and inhibit suppressive immune populations [130, 131]. Compared to tumor types which are considered immunologically "cold" (having very little immune cell infiltration), the rich infiltrates of leukocytes within the liver present an opportunity to use novel immunotherapy combinatorial strategies to re-polarize immune cells to a productive anti-cancer response. Furthermore, strategies targeting suppressive populations such as HSCs and MDSC that worsen fibrosis and impair protective $\mathrm{T}$ cell function are a potential path forward to enhancing the efficacy of CPI. Additionally, tumor cell intrinsic mechanisms of resistance to CPI should be explored. Given that the majority of HCC patients have developed cancer in a background of impaired liver function and liver inflammation, the clinical need for strategies that are both effective and safe in this population is of great importance, as well as determining how best to sequence or combine available agents for HCC. Identification of biomarkers of immune response is also paramount in guiding choice of individual treatments and sequencing therapy. Further correlative and basic science studies should reveal the full potential of the immune system to re-shape the dysfunctional liver tumor microenvironment and overcome the barriers to successful anticancer immunotherapy.

\section{Abbreviations}

AFP: alpha-fetoprotein; APC: antigen-presenting cell; CAF: cancer-associated fibroblast; CD: cluster of differentiation; CPI: checkpoint inhibition; CRP: Creactive protein; $C T L A-4$ : cytotoxic T-lymphocyte-associated antigen 4; CXCL: chemokine (C-X-C motif) ligand; CXCR: C-X-C motif chemokine receptor; DC: dendritic cell; ECM: extracellular matrix; FGF: fibroblast growth factor; HBV: hepatitis B virus; HCC: hepatocellular carcinoma; HCV: hepatitis C virus; HSC: hepatic stellate cell; ICAM-1: intercellular adhesion molecule 1; IDO: indoleamine 2,3-dioxygenase; IFNY: interferon gamma;

IHC: immunohistochemistry; IL: interleukin; KC: Kupffer cell; KIR: killer-cell immunoglobulin-like receptor; LAG3: lymphocyte-activation gene 3; LPS: lipopolysaccharide; LSEC: liver sinusoidal endothelial cell; MAGE-

A1: melanoma-associated gene-A1; MAIT: mucosal-associated invariant T cell; MBL: mannose-binding lectin; MCP-1: monocyte chemoattractant protein-1; MDSC: myeloid-derived suppressor cell; MHC: major histocompatibility complex; MICA: MHC class I-related chain A; MMP: matrix metalloproteinase; NASH: non-alcoholic steatohepatitis; NFkB: nuclear factor kappa B; NK T: natural killer T cell; NK: natural killer cell; NKG2D: natural killer group 2D; NY-ESO-1: New York-esophageal squamous cell carcinoma-1;

PAMP: pathogen-associated molecular patterns; PD-1: programmed cell death protein 1; PDGF: platelet-derived growth factor; PD-L1: programmed death-ligand 1; PMN: polymorphonuclear leukocyte (neutrophil); PRR: pattern recognition receptor; ROS: reactive oxygen species; SOCS1: suppressor of cytokine signaling 1; STAT1: signal transducer and activator of transcription 1; TACE: transcatheter arterial chemoembolization; TAM: tumor-associated macrophage; TCR: T cell receptor; TCRY $\delta$ : TCR gamma delta; Teff: T effector cell (representing $\mathrm{CD}^{+}$and $\mathrm{CD} 4^{+} \mathrm{T}$ effector cells); TGF $\beta$ : transforming growth factor beta; Th1: T helper 1; Th17: T helper 17; TIM3: T-cell 
immunoglobulin and mucin-domain containing-3; TLR: toll-Like receptor; TNFa: tumor necrosis factor alpha; Treg: T regulatory cell; TRM: resident memory T cell; VCAM-1: vascular cell adhesion molecule 1; VEGF: vascular endothelial growth factor; VISTA: V-domain Ig suppressor of T cell activation

\section{Acknowledgements}

Not applicable

\section{Authors' contributions}

BPK conceptualized, wrote, designed the figure, and edited the paper. RKK and LF conceptualized, wrote, and edited the paper. All authors read and approved the final manuscript.

\section{Funding}

Not applicable

\section{Availability of data and materials}

Not applicable

\section{Ethics approval and consent to participate}

Not applicable

\section{Consent for publication}

Not applicable

\section{Competing interests}

BPK: None to declare. LF: Research funding from Abbvie, Bavarian Nordic, BMS, Dendreon, Janssen, Merck, Roche/Genentech. RKK: Research funding to institution for conduct of clinical trials from: Agios, Astra Zeneca, Bayer, BMS, Eli Lilly, Exelixis, Medimmune, Merck, Novartis, QED, Taiho. Steering Committee/Scientific Advisory Committee membership with funding support to institution from: Agios, Astra Zeneca, BMS, Merck. Consulting/IDMC funding to self from: Genentech/Roche, Target Pharma Solutions.

\section{Received: 19 June 2019 Accepted: 20 September 2019}

\section{Published online: 18 October 2019}

\section{References}

1. Giannini EG, Farinati F, Ciccarese F, Pecorelli A, Rapaccini GL, Di Marco M, et al. Prognosis of untreated hepatocellular carcinoma. Hepatology. 2015; 61(1):184-90.

2. Organization WH. Fact sheets by the global Cancer observatory 2018. Available from: http://gco.iarc.fr/today/data/factsheets/populations/900world-fact-sheets.pdf. Accessed 1 Mar 2019.

3. NIH Surveillance E, And end results program. Cancer Stat Facts: Liver and Intrahepatic Bile Duct Cancer 2018. Available from: https://seer.cancer.gov/ statfacts/html/livibd.html. Accessed 1 Mar 2019.

4. El-Serag HB. Hepatocellular carcinoma. N Engl J Med. 2011;365(12):1118-27.

5. White DL, Thrift AP, Kanwal F, Davila J, El-Serag HB. Incidence of hepatocellular carcinoma in all 50 United States, from 2000 through 2012 Gastroenterology. 2017;152(4):812-20 e5.

6. Forner A, Reig M, Bruix J. Hepatocellular carcinoma. Lancet. 2018;391(10127): $1301-14$.

7. Llovet JM, Ricci S, Mazzaferro V, Hilgard P, Gane E, Blanc JF, et al. Sorafenib in advanced hepatocellular carcinoma. N Engl J Med. 2008;359(4):378-90.

8. Topalian SL, Hodi FS, Brahmer JR, Gettinger SN, Smith DC, McDermott DF, et al. Safety, activity, and immune correlates of anti-PD-1 antibody in cancer. N Engl J Med. 2012;366(26):2443-54.

9. Balar AV, Weber JS. PD-1 and PD-L1 antibodies in cancer: current status and future directions. Cancer Immunol Immunother. 2017;66(5):551-64.

10. Postow MA, Callahan MK, Wolchok JD. Immune checkpoint blockade in Cancer therapy. J Clin Oncol. 2015;33(17):1974-82.

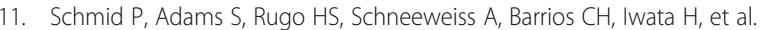
Atezolizumab and nab-paclitaxel in advanced triple-negative breast Cancer. N Engl J Med. 2018;379(22):2108-21.

12. Bellmunt J, de Wit $R$, Vaughn DJ, Fradet $Y$, Lee $J$, Fong $L$, et al. Pembrolizumab as second-line therapy for advanced Urothelial carcinoma. N Engl J Med. 2017:376(11):1015-26.

13. Ferris RL, Blumenschein G Jr, Fayette J, Guigay J, Colevas AD, Licitra L, et al. Nivolumab for recurrent squamous-cell carcinoma of the head and neck. N Engl J Med. 2016;375(19):1856-67.
14. Nghiem PT, Bhatia S, Lipson EJ, Kudchadkar RR, Miller NJ, Annamalai L, et al. PD-1 blockade with Pembrolizumab in advanced Merkel-cell carcinoma. N Engl J Med. 2016;374(26):2542-52.

15. El-Khoueiry AB, Sangro B, Yau T, Crocenzi TS, Kudo M, Hsu C, et al. Nivolumab in patients with advanced hepatocellular carcinoma (CheckMate 040): an open-label, non-comparative, phase 1/2 dose escalation and expansion trial. Lancet. 2017;389(10088):2492-502.

16. Zhu AX, Finn RS, Edeline J, Cattan S, Ogasawara S, Palmer D, et al. Pembrolizumab in patients with advanced hepatocellular carcinoma previously treated with sorafenib (KEYNOTE-224): a non-randomised, openlabel phase 2 trial. Lancet Oncol. 2018;19(7):940-52.

17. Duffy AG, Ulahannan SV, Makorova-Rusher O, Rahma O, Wedemeyer H, Pratt $D$, et al. Tremelimumab in combination with ablation in patients with advanced hepatocellular carcinoma. J Hepatol. 2017;66(3):545-51.

18. Sangro B, Gomez-Martin C, de la Mata M, Inarrairaegui M, Garralda E, Barrera $P$, et al. A clinical trial of CTLA-4 blockade with tremelimumab in patients with hepatocellular carcinoma and chronic hepatitis C. J Hepatol. 2013;59(1): $81-8$

19. Brar G, Greten TF, Brown ZJ. Current frontline approaches in the management of hepatocellular carcinoma: the evolving role of immunotherapy. Ther Adv Gastroenterol. 2018;11:1756284818808086.

20. Inarrairaegui M, Melero I, Sangro B. Immunotherapy of hepatocellular carcinoma: facts and hopes. Clin Cancer Res. 2018;24(7):1518-24.

21. Brown ZJ, Heinrich B, Steinberg SM, Yu SJ, Greten TF. Safety in treatment of hepatocellular carcinoma with immune checkpoint inhibitors as compared to melanoma and non-small cell lung cancer. J Immunother Cancer. 2017; 5(1):93.

22. Kambhampati S, Bauer KE, Bracci PM, Keenan BP, Behr SC, Gordan JD, et al. Nivolumab in patients with advanced hepatocellular carcinoma and childPugh class B cirrhosis: safety and clinical outcomes in a retrospective case series. Cancer. 2019;125(18):3234-41.

23. Krenkel O, Tacke F. Liver macrophages in tissue homeostasis and disease. Nat Rev Immunol. 2017;17(5):306-21.

24. Tumeh PC, Hellmann MD, Hamid O, Tsai KK, Loo KL, Gubens MA et al. Liver metastasis and treatment outcome with anti-PD-1 monoclonal antibody in patients with melanoma and NSCLC. Cancer Immunol Res. 2017:5(5):417-24.

25. Mingozzi F, Liu YL, Dobrzynski E, Kaufhold A, Liu JH, Wang Y, et al. Induction of immune tolerance to coagulation factor IX antigen by in vivo hepatic gene transfer. J Clin Invest. 2003;111(9):1347-56.

26. Akbarpour M, Goudy KS, Cantore A, Russo F, Sanvito F, Naldini L, et al. Insulin B chain 9-23 gene transfer to hepatocytes protects from type 1 diabetes by inducing Ag-specific FoxP3+ Tregs. Sci Transl Med. 2015;7(289): 289 ra81.

27. Gur C, Doron S, Kfir-Erenfeld S, Horwitz E, Abu-Tair L, Safadi R, et al. NKp46mediated killing of human and mouse hepatic stellate cells attenuates liver fibrosis. Gut. 2012;61(6):885-93

28. Tian Z, Chen Y, Gao B. Natural killer cells in liver disease. Hepatology. 2013; 57(4):1654-62

29. Shibolet O, Alper R, Zlotogarov L, Thalenfeld B, Engelhardt D, Rabbani E, et al. NKT and CD8 lymphocytes mediate suppression of hepatocellular carcinoma growth via tumor antigen-pulsed dendritic cells. Int J Cancer. 2003;106(2):236-43.

30. Fattovich G, Stroffolini T, Zagni I, Donato F. Hepatocellular carcinoma in cirrhosis: incidence and risk factors. Gastroenterology. 2004;127(5 Suppl 1): S35-50

31. Woller N, Gurlevik E, Fleischmann-Mundt B, Schumacher A, Knocke S, Kloos AM, et al. Viral infection of tumors overcomes resistance to PD-1immunotherapy by broadening Neoantigenome-directed T-cell responses. Mol Ther. 2015;23(10):1630-40.

32. Racanelli V, Rehermann B. The liver as an immunological organ. Hepatology 2006;43(2 Suppl 1):S54-62.

33. Gao B, Jeong Wl, Tian Z. Liver: an organ with predominant innate immunity. Hepatology. 2008;47(2):729-36.

34. Bilzer M, Roggel F, Gerbes AL. Role of Kupffer cells in host defense and liver disease. Liver Int. 2006;26(10):1175-86

35. Szabo G, Dolganiuc A, Mandrekar P. Pattern recognition receptors: a contemporary view on liver diseases. Hepatology. 2006;44(2):287-98.

36. Shi J, Fujieda H, Kokubo Y, Wake K. Apoptosis of neutrophils and their elimination by Kupffer cells in rat liver. Hepatology. 1996;24(5):1256-63.

37. Heymann F, Tacke F. Immunology in the liver--from homeostasis to disease. Nat Rev Gastroenterol Hepatol. 2016;13(2):88-110. 
38. Bayon LG, Izquierdo MA, Sirovich I, van Rooijen N, Beelen RH, Meijer S. Role of Kupffer cells in arresting circulating tumor cells and controlling metastatic growth in the liver. Hepatology. 1996;23(5):1224-31.

39. Thomson AW, Knolle PA. Antigen-presenting cell function in the tolerogenic liver environment. Nat Rev Immunol. 2010;10(11):753-66.

40. Limmer A, Ohl J, Kurts C, Ljunggren HG, Reiss Y, Groettrup M, et al. Efficient presentation of exogenous antigen by liver endothelial cells to CD8+ T cells results in antigen-specific T-cell tolerance. Nat Med. 2000;6(12):1348-54.

41. Knolle PA, Germann T, Treichel U, Uhrig A, Schmitt E, Hegenbarth S, et al. Endotoxin down-regulates $T$ cell activation by antigen-presenting liver sinusoidal endothelial cells. J Immunol. 1999;162(3):1401-7.

42. Eggert T, Greten TF. Tumor regulation of the tissue environment in the liver. Pharmacol Ther. 2017:173:47-57.

43. Dusseaux M, Martin E, Serriari N, Peguillet I, Premel V, Louis D, et al. Human MAIT cells are xenobiotic-resistant, tissue-targeted, CD161hi IL-17-secreting T cells. Blood. 2011;117(4):1250-9.

44. Won EJ, Ju JK, Cho YN, Jin HM, Park KJ, Kim TJ, et al. Clinical relevance of circulating mucosal-associated invariant $\mathrm{T}$ cell levels and their anti-cancer activity in patients with mucosal-associated cancer. Oncotarget. 2016;7(46): 76274-90.

45. Bandyopadhyay K, Marrero I, Kumar V. NKT cell subsets as key participants in liver physiology and pathology. Cell Mol Immunol. 2016;13(3):337-46.

46. Godfrey DI, Kronenberg M. Going both ways: immune regulation via CD1ddependent NKT cells. J Clin Invest. 2004;114(10):1379-88.

47. Jenne CN, Kubes P. Immune surveillance by the liver. Nat Immunol. 2013; 14(10):996-1006.

48. Fabregat I, Moreno-Caceres J, Sanchez A, Dooley S, Dewidar B, Giannelli G, et al. TGF-beta signalling and liver disease. FEBS J. 2016;283(12):2219-32.

49. Iwai Y, Terawaki S, Ikegawa M, Okazaki T, Honjo T. PD-1 inhibits antiviral immunity at the effector phase in the liver. J Exp Med. 2003;198(1):39-50.

50. Feng S. Spontaneous and induced tolerance for liver transplant recipients. Curr Opin Organ Transplant. 2016:21(1):53-8.

51. Martinez-Llordella M, Lozano JJ, Puig-Pey I, Orlando G, Tisone G, Lerut J, et al. Using transcriptional profiling to develop a diagnostic test of operational tolerance in liver transplant recipients. J Clin Invest. 2008; 118(8):2845-57.

52. Li W, Kuhr CS, Zheng XX, Carper K, Thomson AW, Reyes JD, et al. New insights into mechanisms of spontaneous liver transplant tolerance: the role of Foxp3-expressing CD25+CD4+ regulatory T cells. Am J Transplant. 2008; 8(8):1639-51.

53. Tang Q, Vincenti F. Transplant trials with Tregs: perils and promises. J Clin Invest. 2017;127(7):2505-12

54. Tandon P, Garcia-Tsao G. Bacterial infections, sepsis, and multiorgan failure in cirrhosis. Semin Liver Dis. 2008;28(1):26-42.

55. Noor MT, Manoria P. Immune dysfunction in cirrhosis. J Clin Transl Hepatol. 2017:5(1):50-8.

56. Wiest R, Garcia-Tsao G. Bacterial translocation (BT) in cirrhosis. Hepatology. 2005;41(3):422-33

57. Saitoh O, Sugi K, Lojima K, Matsumoto H, Nakagawa K, Kayazawa M, et al. Increased prevalence of intestinal inflammation in patients with liver cirrhosis. World J Gastroenterol. 1999:5(5):391-6.

58. Pinzani M, Rombouts K, Colagrande S. Fibrosis in chronic liver diseases: diagnosis and management. J Hepatol. 2005:42 Suppl(1):S22-S36.

59. Li JT, Liao ZX, Ping J, Xu D, Wang H. Molecular mechanism of hepatic stellate cell activation and antifibrotic therapeutic strategies. J Gastroenterol. 2008;43(6):419-28

60. Li L, Chen L, Hu L, Liu Y, Sun HY, Tang J, et al. Nuclear factor high-mobility group box 1 mediating the activation of toll-like receptor 4 signaling in hepatocytes in the early stage of nonalcoholic fatty liver disease in mice. Hepatology. 2011;54(5):1620-30.

61. Roh YS, Seki E. Toll-like receptors in alcoholic liver disease, non-alcoholic steatohepatitis and carcinogenesis. J Gastroenterol Hepatol. 2013;28(Suppl 1):38-42

62. Meng F, Wang K, Aoyama T, Grivennikov SI, Paik Y, Scholten D, et al. Interleukin-17 signaling in inflammatory, Kupffer cells, and hepatic stellate cells exacerbates liver fibrosis in mice. Gastroenterology. 2012;143(3):765-76 e3.

63. Heymann F, Peusquens J, Ludwig-Portugall I, Kohlhepp M, Ergen C, Niemietz $P$, et al. Liver inflammation abrogates immunological tolerance induced by Kupffer cells. Hepatology. 2015;62(1):279-91.

64. O'Rourke JM, Sagar VM, Shah T, Shetty S. Carcinogenesis on the background of liver fibrosis: implications for the management of hepatocellular cancer. World J Gastroenterol. 2018;24(39):4436-47.
65. Knittel T, Mehde M, Kobold D, Saile B, Dinter C, Ramadori G. Expression patterns of matrix metalloproteinases and their inhibitors in parenchyma and non-parenchymal cells of rat liver: regulation by TNF-alpha and TGFbeta1. J Hepatol. 1999;30(1):48-60.

66. Tomita K, Tamiya G, Ando S, Ohsumi K, Chiyo T, Mizutani A, et al. Tumour necrosis factor alpha signalling through activation of Kupffer cells plays an essential role in liver fibrosis of non-alcoholic steatohepatitis in mice. Gut. 2006;55(3):415-24

67. Kramer B, Korner C, Kebschull M, Glassner A, Eisenhardt M, Nischalke HD, et al. Natural killer p46High expression defines a natural killer cell subset that is potentially involved in control of hepatitis C virus replication and modulation of liver fibrosis. Hepatology. 2012;56(4):1201-13.

68. Jeong WI, Park O, Gao B. Abrogation of the antifibrotic effects of natura killer cells/interferon-gamma contributes to alcohol acceleration of liver fibrosis. Gastroenterology. 2008;134(1):248-58.

69. Jeong WI, Park O, Radaeva S, Gao B. STAT1 inhibits liver fibrosis in mice by inhibiting stellate cell proliferation and stimulating NK cell cytotoxicity. Hepatology. 2006;44(6):1441-51.

70. Jeong WI, Park O, Suh YG, Byun JS, Park SY, Choi E, et al. Suppression of innate immunity (natural killer cell/interferon-gamma) in the advanced stages of liver fibrosis in mice. Hepatology. 2011:53(4):1342-51.

71. Ma C, Han M, Heinrich B, Fu Q, Zhang Q, Sandhu M, et al. Gut microbiomemediated bile acid metabolism regulates liver cancer via NKT cells. Science. 2018;360(6391):eaan5931

72. Wehr A, Baeck C, Heymann F, Niemietz PM, Hammerich L, Martin C, et al. Chemokine receptor CXCR6-dependent hepatic NK T cell accumulation promotes inflammation and liver fibrosis. J Immunol. 2013;190(10):5226-36.

73. Homann C, Varming K, Hogasen K, Mollnes TE, Graudal N, Thomsen AC, et al. Acquired C3 deficiency in patients with alcoholic cirrhosis predisposes to infection and increased mortality. Gut. 1997:40(4):544-9.

74. Homann C, Garred P, Hasselqvist P, Graudal N, Thiel S, Thomsen AC Mannan-binding protein and complement dependent opsonization in alcoholic cirrhosis. Liver. 1995;15(1):39-44.

75. Altorjay I, Vitalis Z, Tornai I, Palatka K, Kacska S, Farkas G, et al. Mannose-binding lectin deficiency confers risk for bacterial infections in a large Hungarian cohort of patients with liver cirrhosis. J Hepatol. 2010;53(3):484-91

76. Pimentel-Nunes $\mathrm{P}$, Roncon-Albuquerque R Jr, Dinis-Ribeiro M, Leite-Moreira AF. Role of toll-like receptor impairment in cirrhosis infection risk: are we making progress? Liver Int. 2011;31(1):140-1.

77. Lin CY, Tsai IF, Ho YP, Huang CT, Lin YC, Lin CJ, et al. Endotoxemia contributes to the immune paralysis in patients with cirrhosis. J Hepatol. 2007;46(5):816-26.

78. Ekdahl KN, Loof L, Nyberg A, Nilsson UR, Nilsson B. Defective fc receptormediated clearance in patients with primary biliary cirrhosis. Gastroenterology. 1991;101(4):1076-82.

79. Stadlbauer V, Mookerjee RP, Wright GA, Davies NA, Jurgens G, Hallstrom S, et al. Role of toll-like receptors 2, 4, and 9 in mediating neutrophil dysfunction in alcoholic hepatitis. Am J Physiol Gastrointest Liver Physiol. 2009;296(1):G15-22.

80. Gronbaek H, Sandahl TD, Mortensen C, Vilstrup H, Moller HJ, Moller S. Soluble CD163, a marker of Kupffer cell activation, is related to portal hypertension in patients with liver cirrhosis. Aliment Pharmacol Ther. 2012; 36(2):173-80.

81. Gabele E, Muhlbauer M, Paulo H, Johann M, Meltzer C, Leidl F, et al. Analysis of monocyte chemotactic protein-1 gene polymorphism in patients with spontaneous bacterial peritonitis. World J Gastroenterol. 2009;15(44):5558-62.

82. Zimmermann HW, Seidler S, Nattermann J, Gassler N, Hellerbrand C, Zernecke $\mathrm{A}$, et al. Functional contribution of elevated circulating and hepatic non-classical CD14CD16 monocytes to inflammation and human liver fibrosis. PLoS One. 2010;5(6):e11049.

83. Albillos A, Hera Ad Ade L, Reyes E, Monserrat J, Munoz L, Nieto M, et al. tumour necrosis factor-alpha expression by activated monocytes and altered T-cell homeostasis in ascitic alcoholic cirrhosis: amelioration with norfloxacin. J Hepatol. 2004;40(4):624-31.

84. Laso FJ, Almeida J, Torres E, Vaquero JM, Marcos M, Orfao A. Chronic alcohol consumption is associated with an increased cytotoxic profile of circulating lymphocytes that may be related with the development of liver injury. Alcohol Clin Exp Res. 2010;34(5):876-85.

85. Tedesco D, Thapa M, Gumber S, Elrod EJ, Rahman K, lbegbu CC, et al. CD4(+) Foxp3(+) T cells promote aberrant immunoglobulin $\mathrm{G}$ production 
and maintain CD8(+) T-cell suppression during chronic liver disease. Hepatology. 2017;65(2):661-77.

86. Hou L, Jie Z, Desai M, Liang Y, Soong L, Wang T, et al. Early IL-17 production by intrahepatic $T$ cells is important for adaptive immune responses in viral hepatitis. J Immunol. 2013;190(2):621-9.

87. Li K, Liu H, Guo T. Th17/Treg imbalance is an indicator of liver cirrhosis process and a risk factor for HCC occurrence in HBV patients. Clin Res Hepatol Gastroenterol. 2017;41(4):399-407.

88. Li X, Su Y, Hua X, Xie C, Liu J, Huang Y, et al. Levels of hepatic Th17 cells and regulatory $T$ cells upregulated by hepatic stellate cells in advanced HBV-related liver fibrosis. J Transl Med. 2017;15(1):75.

89. Wherry EJ. T cell exhaustion. Nat Immunol. 2011;12(6):492-9.

90. Boni C, Fisicaro P, Valdatta C, Amadei B, Di Vincenzo P, Giuberti T, et al. Characterization of hepatitis B virus (HBV)-specific T-cell dysfunction in chronic HBV infection. J Virol. 2007:81(8):4215-25.

91. Gardiner D, Lalezari J, Lawitz E, DiMicco M, Ghalib R, Reddy KR, et al. A randomized, double-blind, placebo-controlled assessment of BMS-936558, a fully human monoclonal antibody to programmed death-1 (PD-1), in patients with chronic hepatitis C virus infection. PLoS One. 2013;8(5):e63818

92. Bottcher K, Rombouts K, Saffioti F, Roccarina D, Rosselli M, Hall A, et al. MAIT cells are chronically activated in patients with autoimmune liver disease and promote profibrogenic hepatic stellate cell activation. Hepatology. 2018; 68(1):172-86.

93. Yong YK, Saeidi A, Tan HY, Rosmawati M, Enstrom PF, Batran RA, et al. Hyper-Expression of PD-1 Is Associated with the Levels of Exhausted and Dysfunctional Phenotypes of Circulating CD161(++)TCR iValpha7.2(+) Mucosal-Associated Invariant T Cells in Chronic Hepatitis B Virus Infection. Front Immunol. 2018:9:472

94. Kasper HU, Drebber U, Stippel DL, Dienes HP, Gillessen A. Liver tumor infiltrating lymphocytes: comparison of hepatocellular and cholangiolar carcinoma. World J Gastroenterol. 2009;15(40):5053-7.

95. Wada Y, Nakashima O, Kutami R, Yamamoto O, Kojiro M. Clinicopathological study on hepatocellular carcinoma with lymphocytic infiltration. Hepatology. 1998;27(2):407-14

96. Zheng C, Zheng L, Yoo JK, Guo H, Zhang Y, Guo X, et al. Landscape of infiltrating $T$ cells in liver Cancer revealed by single-cell sequencing. Cell. 2017;169(7):1342-56 e16

97. Cai L, Zhang Z, Zhou L, Wang H, Fu J, Zhang S, et al. Functional impairment in circulating and intrahepatic NK cells and relative mechanism in hepatocellular carcinoma patients. Clin Immunol. 2008;129(3):428-37.

98. Unitt E, Rushbrook SM, Marshall A, Davies S, Gibbs P, Morris LS, et al. Compromised lymphocytes infiltrate hepatocellular carcinoma: the role of Tregulatory cells. Hepatology. 2005;41(4):722-30

99. Zhou G, Sprengers D, Boor PPC, Doukas M, Schutz H, Mancham S, et al. Antibodies against immune checkpoint molecules restore functions of tumor-infiltrating $T$ cells in hepatocellular carcinomas. Gastroenterology. 2017:153(4):1107-19 e10

100. Yuen MF, Norris $S$. Expression of inhibitory receptors in natural killer $(\mathrm{CD} 3(-) \mathrm{CD} 56(+))$ cells and CD3(+)CD56(+) cells in the peripheral blood lymphocytes and tumor infiltrating lymphocytes in patients with primary hepatocellular carcinoma. Clin Immunol. 2001;101(3):264-9.

101. Li T, Yang Y, Hua X, Wang G, Liu W, Jia C, et al. Hepatocellular carcinomaassociated fibroblasts trigger NK cell dysfunction via PGE2 and IDO. Cancer Lett. 2012;318(2):154-61.

102. Jinushi M, Takehara T, Tatsumi T, Hiramatsu N, Sakamori R, Yamaguchi S, et al. Impairment of natural killer cell and dendritic cell functions by the soluble form of MHC class I-related chain a in advanced human hepatocellular carcinomas. J Hepatol. 2005;43(6):1013-20.

103. Liu YT, Tseng TC, Soong RS, Peng CY, Cheng YH, Huang SF, et al. A novel spontaneous hepatocellular carcinoma mouse model for studying T-cell exhaustion in the tumor microenvironment. J Immunother Cancer. 2018:6(1):144.

104. Hoechst B, Ormandy LA, Ballmaier M, Lehner F, Kruger C, Manns MP, et al. A new population of myeloid-derived suppressor cells in hepatocellular carcinoma patients induces CD4(+)CD25(+)Foxp3(+) T cells Gastroenterology. 2008;135(1):234-43.

105. Mise M, Arii S, Higashituji H, Furutani M, Niwano M, Harada T, et al. Clinical significance of vascular endothelial growth factor and basic fibroblast growth factor gene expression in liver tumor. Hepatology. 1996;23(3):455-64.

106. Chew V, Lai L, Pan L, Lim CJ, Li J, Ong R, et al. Delineation of an immunosuppressive gradient in hepatocellular carcinoma using high- dimensional proteomic and transcriptomic analyses. Proc Natl Acad Sci U S A. 2017;114(29):E5900-E9.

107. Chen KJ, Lin SZ, Zhou L, Xie HY, Zhou WH, Taki-Eldin A, et al. Selective recruitment of regulatory $T$ cell through CCR6-CCL20 in hepatocellular carcinoma fosters tumor progression and predicts poor prognosis. PLoS One. 2011;6(9):e24671.

108. Yang L, Inokuchi S, Roh YS, Song J, Loomba R, Park EJ, et al. Transforming growth factor-beta signaling in hepatocytes promotes hepatic fibrosis and carcinogenesis in mice with hepatocyte-specific deletion of TAK1. Gastroenterology. 2013;144(5):1042-54 e4.

109. Dituri F, Mancarella S, Cigliano A, Chieti A, Giannelli G. TGF-beta as multifaceted orchestrator in HCC progression: signaling, EMT, immune microenvironment, and novel therapeutic perspectives. Semin Liver Dis. 2019;39(1):53-69.

110. Yan W, Liu X, Ma H, Zhang H, Song X, Gao L, et al. Tim-3 fosters HCC development by enhancing TGF-beta-mediated alternative activation of macrophages. Gut. 2015;64(10):1593-604.

111. Wu K, Kryczek I, Chen L, Zou W, Welling TH. Kupffer cell suppression of CD8+ T cells in human hepatocellular carcinoma is mediated by $\mathrm{B} 7-\mathrm{H} 1$ programmed death-1 interactions. Cancer Res. 2009;69(20):8067-75.

112. Yarchoan $M$, Xing D, Luan L, Xu H, Sharma RB, Popovic A, et al. Characterization of the immune microenvironment in hepatocellular carcinoma. Clin Cancer Res. 2017;23(23):7333-9.

113. Shalapour S, Lin XJ, Bastian IN, Brain J, Burt AD, Aksenov AA, et al. Inflammation-induced IgA+ cells dismantle anti-liver cancer immunity. Nature. 2017:551(7680):340-5.

114. Inada Y, Mizukoshi E, Seike T, Tamai T, lida N, Kitahara M, et al. Characteristics of immune response to tumor-associated antigens and immune cell profile in patients with hepatocellular carcinoma. Hepatology. 2019:69(2):653-65.

115. Lim CJ, Lee YH, Pan L, Lai L, Chua C, Wasser M, et al. Multidimensional analyses reveal distinct immune microenvironment in hepatitis $B$ virusrelated hepatocellular carcinoma. Gut. 2019;68:916-927.

116. Chew V, Tow C, Teo M, Wong HL, Chan J, Gehring A, et al. Inflammatory tumour microenvironment is associated with superior survival in hepatocellular carcinoma patients. J Hepatol. 2010:52(3):370-9.

117. Unitt E, Marshall A, Gelson W, Rushbrook SM, Davies S, Vowler SL, et al. Tumour lymphocytic infiltrate and recurrence of hepatocellular carcinoma following liver transplantation. J Hepatol. 2006;45(2):246-53.

118. Kenna T, Golden-Mason L, Norris S, Hegarty JE, O'Farrelly C, Doherty DG. Distinct subpopulations of gamma delta T cells are present in normal and tumor-bearing human liver. Clin Immunol. 2004;113(1):56-63.

119. Chew V, Chen J, Lee D, Loh E, Lee J, Lim KH, et al. Chemokine-driven lymphocyte infiltration: an early intratumoural event determining long-term survival in resectable hepatocellular carcinoma. Gut. 2012;61(3):427-38.

120. Lin YC, Hsu CY, Huang SK, Fan YH, Huang CH, Yang CK, et al. Induction of liver-specific intrahepatic myeloid cells aggregation expands CD8 T cell and inhibits growth of murine hepatoma. Oncoimmunology. 2018; 7(12):e1502129.

121. Zhang M, Pang HJ, Zhao W, Li YF, Yan LX, Dong ZY, et al. VISTA expression associated with CD8 confers a favorable immune microenvironment and better overall survival in hepatocellular carcinoma. BMC Cancer. 2018;18(1):511.

122. Blando J, Sharma A, Higa MG, Zhao H, Vence L, Yadav SS, et al. Comparison of immune infiltrates in melanoma and pancreatic cancer highlights VISTA as a potential target in pancreatic cancer. Proc Natl Acad Sci U S A. 2019; 116(5):1692-7.

123. Kuklinski LF, Yan S, Li Z, Fisher JL, Cheng C, Noelle RJ, et al. VISTA expression on tumor-infiltrating inflammatory cells in primary cutaneous melanoma correlates with poor disease-specific survival. Cancer Immunol Immunother. 2018;67(7):1113-21.

124. Vrecko S, Guenat D, Mercier-Letondal P, Faucheu H, Dosset M, Royer B, et al. Personalized identification of tumor-associated immunogenic neoepitopes in hepatocellular carcinoma in complete remission after sorafenib treatment. Oncotarget. 2018;9(83):35394-407.

125. Mizukoshi E, Nakamoto Y, Arai K, Yamashita T, Sakai A, Sakai Y, et al. Comparative analysis of various tumor-associated antigen-specific t-cell responses in patients with hepatocellular carcinoma. Hepatology. 2011; 53(4):1206-16.

126. Flecken T, Schmidt N, Hild S, Gostick E, Drognitz O, Zeiser R, et al. Immunodominance and functional alterations of tumor-associated antigen- 
specific CD8+ T-cell responses in hepatocellular carcinoma. Hepatology. 2014;59(4):1415-26.

127. Willimsky G, Schmidt K, Loddenkemper C, Gellermann J, Blankenstein T. Virus-induced hepatocellular carcinomas cause antigen-specific local tolerance. J Clin Invest. 2013;123(3):1032-43.

128. Yarchoan M, Hopkins A, Jaffee EM. Tumor mutational burden and response rate to PD-1 inhibition. N Engl J Med. 2017;377(25):2500-1.

129. Brown Z, Heinrich B, Greten TF. Mouse models of hepatocellular carcinoma: an overview and highlights for immunotherapy research. Nat Rev Gastroenterol Hepatol. 2018;15(9):536-54.

130. Li G, Liu D, Cooper TK, Kimchi ET, Qi X, Avella DM, et al. Successful chemoimmunotherapy against hepatocellular cancer in a novel murine model. J Hepatol. 2017;66(1):75-85.

131. Chen Y, Ramjiawan RR, Reiberger T, Ng MR, Hato T, Huang Y, et al. CXCR4 inhibition in tumor microenvironment facilitates anti-programmed death receptor-1 immunotherapy in sorafenib-treated hepatocellular carcinoma in mice. Hepatology. 2015;61(5):1591-602.

132. Gopalakrishnan V, Spencer CN, Nezi L, Reuben A, Andrews MC, Karpinets TV, et al. Gut microbiome modulates response to anti-PD-1 immunotherapy in melanoma patients. Science. 2018;359(6371):97-103.

\section{Publisher's Note}

Springer Nature remains neutral with regard to jurisdictional claims in published maps and institutional affiliations.

Ready to submit your research? Choose BMC and benefit from:

- fast, convenient online submission

- thorough peer review by experienced researchers in your field

- rapid publication on acceptance

- support for research data, including large and complex data types

- gold Open Access which fosters wider collaboration and increased citations

- maximum visibility for your research: over $100 \mathrm{M}$ website views per year

At BMC, research is always in progress. 